\title{
СОЦИОЛОГИЯ МИГРАЦИИ
}

DOI: 10.24290/1029-3736-2020-26-4-185-204

\section{ОСОБЕННОСТЬ ЭТНОСОЦИАЛЬНЫХ КОНФЛИКТОВ НА РОССИЙСКОМ РЫНКЕ ТРУДА: ОТНОШЕНИЕ К ИММИГРАНТАМ В РОССИИ (НА ПРИМЕРЕ Г. МОСКВЫ). СРАВНИТЕЛЬНЫЙ АНАЛИЗ СО СТРАНАМИ ЗАПАДНОЙ ЕВРОПЫ}

\begin{abstract}
А.А. Осеев, докт. социол. наук, проф., доц. кафедры экономической социологии и менеджмента социологического факультета МГУ имени М.В. Ломоносова, Ленинские горы, МГУ, д. 1. стр. 33, г. Москва, Российская Федерация, $119234^{*}$
\end{abstract}

Ф.А. Дудуева, преподаватель-исследователь, асп. кафедры экономической социологии и маркетинга социологического факультета МГУ имени М.В. Ломоносова, Ленинские горы, МГУ, д. 1. стр. 33, г. Москва, Российская Федерация, $119234^{* *}$

В развитии темы проводимых исследований и уже опубликованных работ ${ }^{1}$ в статье раскрьвается особенность этносоииальньх конфликтов на рынке труда в России (на примере г. Москвы). Анализируется состояние этно-социальных конфликтов на рынке труда с позиции социально-психологической парадигмы конфликтологии (Л.Козер, К. Райт, К. Лорени, А. Харитонов и другие). Показано, что проблема межэтнической напряженности является достаточно актуальной для ньнешней России.

В статье показано отношение местного населения г. Москвы к трудовым мигрантам (позитивные и негативные последствия миграции), отношение к динамике трудовой миграции, к случаям негативного отношения к трудовым мигрантам. Показаны частота, причинь, сферь жизнедеятельности, в которьх респондент был непосредственным участником, и способы их урегулирования.

* Осеев Александр Александрович, e-mail: oseev.a@mail.ru

** Дудуева Фариза Арсланбековна, e-mail: fariza-elvira@mail.ru

${ }^{1}$ Осеев А.А., Дудуева Ф.А. Особенность этно-социальных конфликтов на российском рынке труда: отношение к иммигрантам в России и Великобритании сравнительный анализ // Вестник Московского университета. Серия 18. Социология и политология. 2015. № 4; Oseev A.A., Dudueva F.A., Karacsony P., Vinichenko M.V., Makushkin S.A. The peculiarity of the ethno-social conflicts in the Russian labor market: comparative analysis of Russia, Great Britain and Germany // La peculiaridad de los conflictos etno-sociales en el Mercado laboral en Rusia: un análisis comparativo de Rusia, Gran Bretaña y Alemania. Revista ESPACIOS. 2018. Vol. 39. N 22. P. 12. 
Причины, которые разделяют людей разной начиональностей. Приводится сравнительный анализ отношения к иммигрантам в России, Великобритании, Германии и Франции.

Ключевые слова: этносоциальный конфликт, сочиальная напряженность в обществе, межэтническая напряженность, трудовая миграция, отнотение к иммигрантам в России, Великобритании, Германии и Франиии. Частота, причины, сферы жизнедеятельности и способы урегулирования конфликтов.

\section{THE PECULIARITY OF ETHNO-SOCIAL} RELATIONS IN THE RUSSIAN LABOR MARKET: ATTITUDE TOWARDS IMMIGRANTS IN RUSSIA (ON THE EXAMPLE OF MOSCOW). COMPARATIVE ANALYSIS WITH COUNTRIES OF WESTERN EUROPE

\footnotetext{
Oseev Alexander A., Doctor of Sociology, Professor, Associate Professor of Economic Sociology and Management Department, Faculty of sociology, Lomonosov Moscow State University, Leninsky Gory, 1-33, Moscow, Russian Federation, 119234, e-mail: oseev.a@ mail.ru
}

Dudueva Fariza A., Instructor-Researcher, Graduated from Graduate school at the Economic Sociology and Management Department, Faculty of sociology, Lomonosov Moscow State University, Leninsky Gory, 1-33, Moscow, Russian Federation, 119234, e-mail: fariza-elvira@mail.ru

In developing the topic of ongoing research and already published works, the article reveals the peculiarity of ethno-social conflicts on the labor market in Russia (for example, Moscow). The state of ethno-social conflicts in the labor market is analyzed from the perspective of the socio-psychological paradigm of conflict management (L. Coser, C. Wright, K. Lorenz, A. Kharitonov and others). It is shown that the problem of interethnic tension is quite relevant for today's Russia.

The article shows the attitude of the local population of Moscow towards labor migrants (positive and negative consequences of migration), their attitude to the dynamics of labor migration, and to cases of negative attitudes towards labor migrants. The frequency, causes, spheres of life in which the respondent was a direct participant, and how to resolve them are shown. Reasons that divide people of different nationalities. A comparative analysis of attitudes towards immigrants in Russia, the UK, Germany and France is given.

Key words: ethno-social conflict, social tension in society, interethnic tension, labor migration, attitude towards immigrants in Russia, Great Britain, Germany and France. Frequency, causes, spheres of life and ways to resolve conflicts. 


\section{1. Актуальность и методологические основы исследования проблем этносоциальных конфликтов на российском рынке труда}

В одной из ранее опубликованных работ² отмечалось, что актуальность проблемы исследования обусловлена ростом в мире вообще и в России в частности, количества этносоциальных конфликтов. Возникающие в обществе этнические взаимодействия в ряде случаев завершаются конфликтами, которые в конечном счете приводят к негативным последствиям. В частности, растет количество преступлений на национальной почве, усиливается этническая неприязнь, происходит всплеск этнического национализма, что приводит к социальной напряженности, которая зачастую приобретает формы силового, и даже вооруженного противоборства. Представители современного общества подвержены разным этническим стереотипам, которые мешают представителям различных этносов поддерживать толерантное отношение друг к другу.

Этносоциальные проблемы актуальны и для сегодняшней России, поскольку помимо того, что страна является многонациональным государством, в последнее время наблюдается большой приток трудовых мигрантов в различные субъекты Российской Федерации. Данная тенденция становится еще одной причиной возникновения противоречий между мигрантами и титульными этносами принимающих стран и регионов. Основной проблемой является дешевая рабочая сила мигрантов, которая серьезно теснит предложения со стороны конкурентов из местных жителей. В связи с этим исследование особенностей этносоциальных конфликтов на российском рынке труда приобретает особую актуальность

Анализируя состояние этносоциальных конфликтов на российском рынке труда с позиции социально-психологической парадигмы конфликтологии (развивалась Л. Козером ${ }^{3}$ К. Райтом, К. Лоренцем, А. Харитоновым, В.О. Рукавишниковым и другими исследователями ${ }^{4}$ ) было показано, что проблема этнической напряженности является достаточно актуальной. Социальная напряженность представляет собой эмоциональное состояние группы или общества в целом, вызванное давлением природной или социальной среды и продолжающееся, как правило, в течение более или менее длительного времени ${ }^{5}$. Социальная напряженность как эмоциональное состояние группы

${ }^{2}$ Осеев А.А., Дудуева Ф.А. Указ. соч.

${ }^{3}$ Козер Л. Функции социального конфликта. М., 2000. С. 47.

${ }^{4}$ Зайщев А.К. Социальный конфликт. М., 2001. С. 25-32; Уткин Э.А. Конфликтология. Теория и практика. М., 1998. С. 103, 111, 114.

${ }^{5}$ Дмитриев А.В. Конфликтология. М., 2002. 
или общества в целом является важным теоретическим и практическим понятием, поскольку раскрывает социальные и психологические причины конфликта. Теория социальной напряженности (или социально-психологическая парадигма конфликтологии), в отличии от социально-биологической парадигмы, которая видит источник социального конфликта в биологической природе человека (Ч. Дарвин, 3. Фрей, Ж. Делгадо, К. Лоренц и др. - инстинкты, расстройства, эндокринные процессы и пр., плюс воспитание), классовой (К. Маркс, Ф. Энгельс, В.И. Ленин и др.), которая считает источником конфликта разделение людей на различные классы в соответствии с их положением в экономической системе, структурно-функциональной, где источником конфликта является искажение, дисфункциональный процесс в социальных система, нарушение гомеостаза социальных систем (Т. Парсонс) и других парадигм, показывает, что причиной конфликта является, с одной стороны, реальные социально-экономические проблемы, вызывающие неудовлетворенность человека условиями жизни, своим социальным, экономическим и политическим положением, и, с другой, определенное психологическое состояние человека - депривация - состояние неудовлетворенности потребностей.

В понятии “социальная напряженность” отразились идеи Р. Дарендорфа, выделявшего три ключевых момента в изучении социального конфликта: 1) каким образом в структуре общества возникают конфликтующие группы; 2) какие формы принимает борьба конфликтующих групп; 3) как влияет групповой конфликт на изменение социальной структуры.

С позиции данного методологичекосго подхода ${ }^{6}$ проводился сравнительный анализ отношения к иммигрантам в России и Западной Европе. Представленные данные социологических исследований показали, что несмотря на наличие межэтнической напряженности в российском обществе наблюдается высокий уровень этнической толерантности.

Дальнейшие исследования проведенные в период с 2015 по 2018 г. показали, что несмотря на высокий уровень этно-социальных конфликтов в России, их число и формы проявления (агрессивность) значительно ниже, чем в странах Западной Европы, а россияне в большей мере “толерантны” к представителям других этносов, чем жители, например, таких стран, как Франция, Англия и Германия ${ }^{7}$.

\footnotetext{
${ }^{6}$ Методологические основы исследования подробно изложены в работе: Осеев А.А., Дудуева Ф.А. Указ. соч.

${ }^{7}$ Oseev A.A., Dudueva F.A., Karacsony P., Vinichenko M.V., Makushkin S.A. Op. cit. P. 12.
} 
На основе проведенных исследований можно сделать вывод о том, что в России объективно существует потребность в привлечении иностранной рабочей силы. Об этом свидетельствуют демографические прогнозы экспертов. Более того, нынешняя экономическая ситуация в стране также формирует дефицит трудовых ресурсов. В связи с социокультурными различиями работников-мигрантов и местного населения возникают различные этнические стереотипы, ложные мифы, межэтническая напряженность, и как следствие, этно-социальный конфликты. Что говорит о насущной, необходимости заниматься вопросами оптимизации системы социальной адаптации трудовых мигрантов на государственном уровне и на уровне гражданского общества. Этому может способствовать только эффективная миграционная, демографическая и экономическая политика государства, основанная на принципах государственной национальной политики РФ и соответствующей стратегии до 2025 г.

В 2018 г. было решено провести углубленные исследования состояние особенность этносоциальных конфликтов на российском рынке труда: отношение к иммигрантам в России. Объектом авторского исследования был выбран г. Москва со всеми существующими на тот момент проблемами в области этносоциальных конфликтов на российском рынке труда. Были получены интересные результаты, с которыми мы решили познакомить читателей авторитетного журнала. Несмотря на то, что результаты носят предварительный характер, поскольку проводились в рамках пилотажных исследований на ограниченной выборке и потому не претендуют на всестороннее освещение проблемы, они хорошо показывают тенденции в состоянии социальной напряженности в области этносоциальных конфликтов. Могут послужить хорошей методической и информационной основой для проведения подобных исследований нашими коллегами в других вузах и исследовательских центрах.

\section{2. Особенность этносоциальных конфликтов на российском рынке труда: отношение к иммигрантам в России (на примере г. Москвы)}

Методом случайной выборки было опрошено 225 респондентов, живущих в Москве, являющихся представителями тех национальностей, которые входят в список коренных этносов России. По сферам деятельности респонденты, как показал анализ, представляли разные сферы занятости и распределились следующим образом: 1) промышленность - 4\%, 2) строительство - 4,9, 3) сельское хо- 
зяйство - $0,4,4)$ транспорт $-4,4,5)$ наука $-5,8,6)$ образование $11,6,7)$ искусство и культура - 6,7, 8) здравоохранение - 7,6, 9) торговля - 11,6, 10) соцобеспечение - $1,3,11$ ) общественное питание $-1,3,12$ ) жилищно-коммунальное хозяйство (ЖКХ) $-2,2$, 13) органы государственного управления - 6,2,14) финансы - 12,9, $15)$ информационные технологии $-4,4,16)$ средства массовой информации (СМИ) - 3,6\%.

Сразу хотелось бы отметить, что результаты проведенного социологического исследования об отношении местного населения Москвы к приезжим мигрантам, свидетельствуют о том, что, несмотря на имеющиеся случаи этнической напряженности в стране, граждане России проявляют высокий уровень этнической толерантности друг к другу. Рассмотрим полученные результаты.

\section{1. Как Вы считаете?}

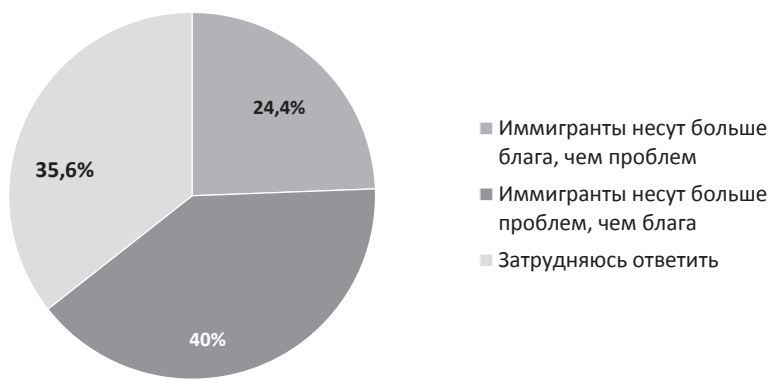

Рис. 1. Отношение местного населения Москвы к трудовым мигрантам

3. В чем, по Вашему мнению, позитивные последствия трудовой миграции

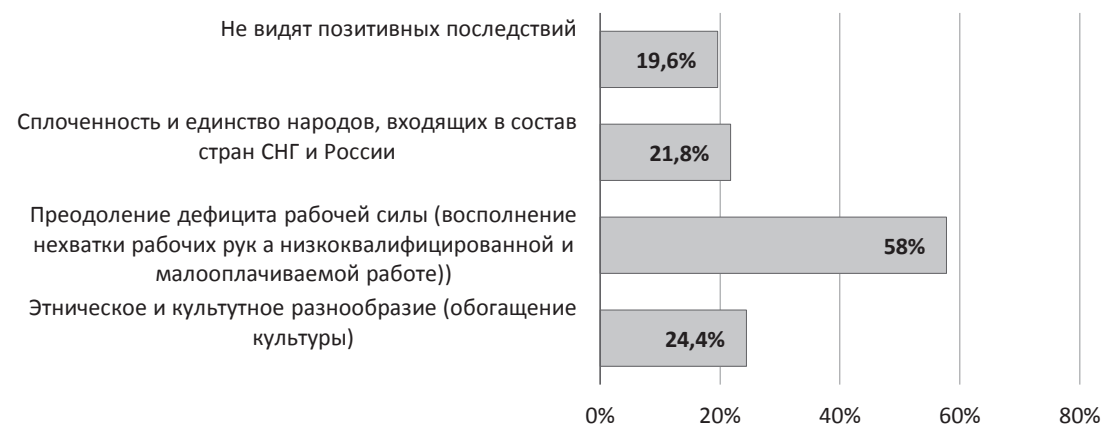

Рис. 3 
Несмотря на то, что 40\% респондентов считают, что иммигранты несут больше проблем, чем блага, 35,6\% затрудняются ответить на данный вопрос. Сравнивая данные полученные в ходе опроса, проведенного Французским Университетом общественного мнения в октябре 2013 г., согласно которому 46\% респондентов считают, что уровень безработицы может сократиться только за счет сокращения иммиграции в стране ${ }^{8}$, стоит заметить важное отличие. Результаты авторского исследования показали, что $44,9 \%$ респондентов позитивно относятся к тому, что трудовые мигранты в России уже занимают рабочие места в важных отраслях экономики страны (транспорт, строительство, сельское хозяйство и прочее).

2. Как вы относитесь к тому, что трудовые мигранты в Росии занимают рабочие места в важных отраслях экономики страны (транспорт, строительство, сельское хозяйство и прочее)

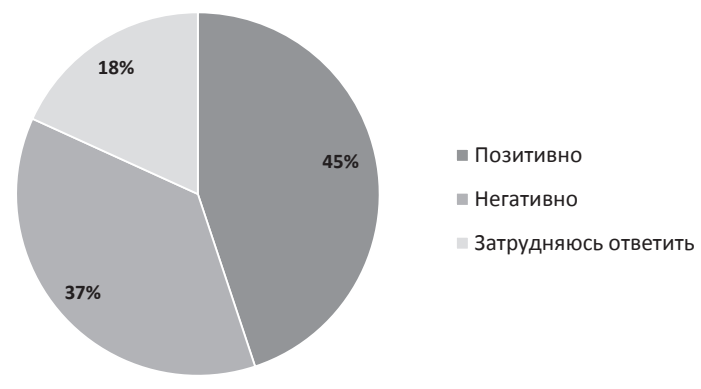

Рис. 2

Данные результаты говорят о том, что большинство респондентов поддерживают идею привлечения иностранной рабочей силы для восполнения нехватки рабочих рук в стране. К тому же, респонденты отмечают ряд позитивных последствий трудовой миграции, что, безусловно, свидетельствует о положительной тенденции в сфере межэтнических отношений в российском обществе.

Позитивные последствия трудовой миграции. В качестве позитивных последствий выделены: преодоление дефицита рабочей силы (восполнение нехватки рабочих рук на низкоквалифицированной и малооплачиваемой работе) - 58\%, а также этническое культурное разнообразие (обогащение культуры) - 24,4\%. Данные

${ }^{8}$ Отношение европейцев к Исламу и мусульманам: Великобритания, Германия, Франция. URL: http://islam-today.ru/obsestvo/otnoshenie_evropejcev_k_islamu_i_ musulmanam_velikobritaniya_germaniya_franciya/ (дата обращения: 01.02.2013). 
факты свидетельствуют о том, что представители местного населения осознают необходимость привлечения иностранной рабой силы и проявляют высокий уровень этнической толерантности, рассматривая обогащение культуры как позитивное последствие современных миграционных процессов в стране.

Несмотря на отмеченные позитивные последствия трудовой миграции, респонденты указали и на наличие негативных последствий.

4. В чем, по Вашему мнению, негативные последствия трудовой миграции?

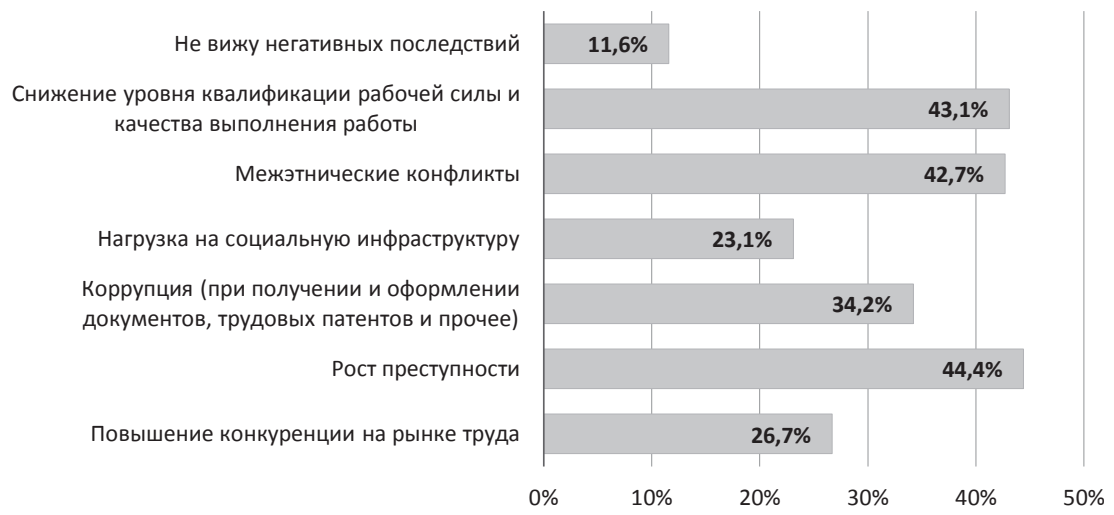

Рис. 4

Негативные последствия трудовой мигращии. Несмотря на тот факт, что по данным МВД преступность среди иностранцев в 2017 г. по сравнению с 2016 снизилась на 10\%, а также, количество преступлений в отношении иностранных граждан сократилось на $10,5 \%$, до 8,1 тыс. случаев, 44,4\% респондентов считают негативным последствием трудовой миграции - рост преступности. На втором месте среди негативных последствий отмечалось снижение уровня квалификации рабочей силы и качества выполнения работы $(43,1 \%)$. На третьем месте - межэтнические конфликты $(42,7 \%)$. В связи с этим важно отметить, что необходимо усилить контроль со стороны правоохранительных органов за преступностью среди иностранных рабочих. К тому же, новейшая система мониторинга межнациональных конфликтов, реализуемая в настоящее время ФАДН должна, в свою очередь, способствовать пресечению возможной преступности со стороны лиц являющихся иностранными гражданами. 
5. Как вы оцениваете отношение местного населения к мигрантам в настоящее время?
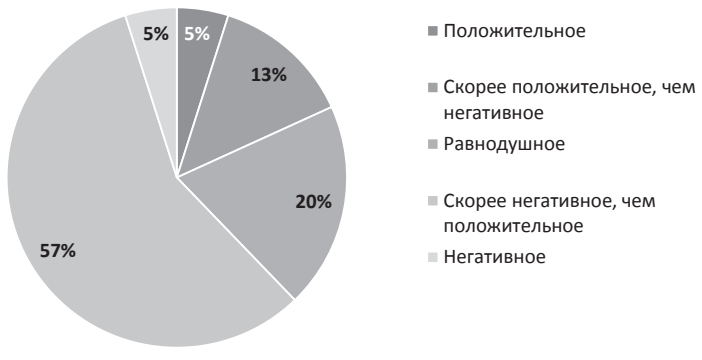

Рис. 5

В целом характеризуя ситуацию, 57,3\% опрошенных оценивают отношение местного населения к мигрантам в настоящее время как скорее негативное, чем положительное, $20 \%$ считают, что оно равнодушное. Как положительное и скорее положительное, чем негативное оценивают 5\% и 13\%, соответственно. При этом интересна динамика отношения к мигрантам за последние два-три года.

Какова динамика отношения к мигрантам за последние два-три года? (Один из показателей эффективности проводимой межнациональной политики.) Исследования показали, что 33,8\% считают, что оно стало лучше, $20 \%$ считают, что отношение к мигрантам ухудшилось, $46,2 \%$ отметили, что оно осталось на прежнем уровне.

6. Как Вы считаете: какова динамика отношения местного населения к мигрантам за последние 2-3 года?

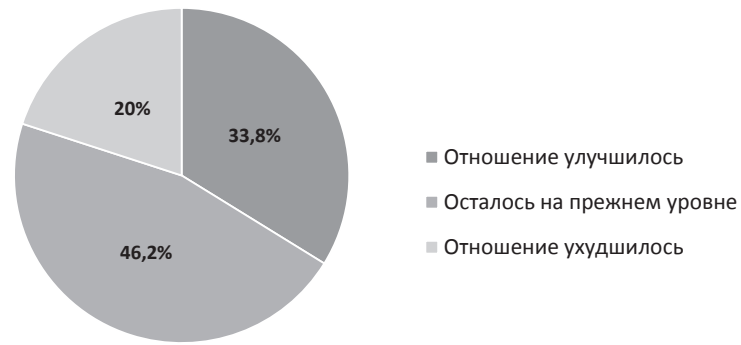

Рис. 6

Мнение о том - нужно или не нужно сокращать число трудовых мигрантов разделилось. 30,2\% выразили мнение, что сокращать 
число мигрантов не нужно, поскольку в России много рабочих мест, которые могут занять трудовые мигранты без ущерба для местного населения. Стоит отметить, что это достаточно хороший показатель, который свидетельствует о том, что представители местного населения Москвы осознают существующую потребность привлечения иностранных рабочих на российский рынок труда. $46,2 \%$ считают, что число трудовых мигрантов в России нужно сократить (их становится слишком много). (В “толерантной” Великобритании, об этом чуть позже, - 54\%!) Это, в свою очередь, подтверждает, что проблема этносоциальных конфликтов актуальна для российского общества и необходимо совершенствовать методы их минимизации в стране.

\section{7. Как Вы считаете: надо или не надо сократить число трудовых мигрантов в России?}

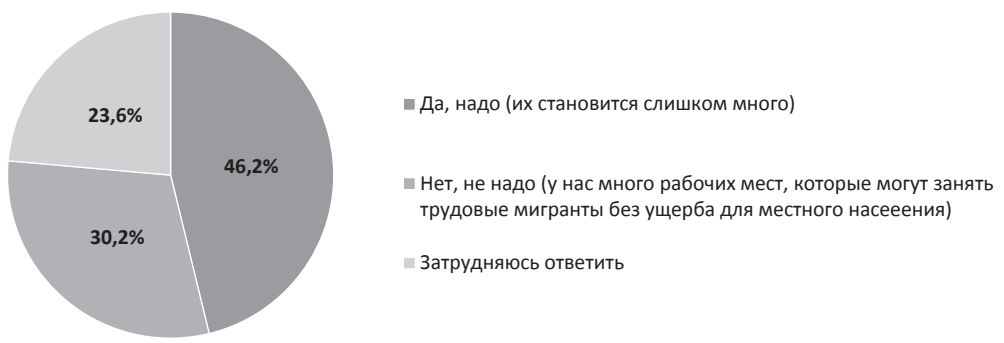

Рис. 7

На том фоне интересны результаты нового опроса, проведенного в Великобритании.

Согласно социологическому исследованию, проведенному в конце 2019 г. компанией Ipsos Mori и организацией по защите прав мигрантов $\mathrm{iMix}^{9}$, в Великобритании наблюдается смягчение отношения британцев к иммиграции: “47\% респондентов полагают, что иммиграция оказала благотворное влияние на страну, а 29\% уверены, что миграция привела к негативным последствиям”. При этом большинство - “54\% хотели бы видеть в Великобритании меньше приезжих”. Правда, количество таких людей в сравнении с июнем 2015 “сократилось с 66\%”.

9 Astons - ведущая международная компания, специализирующаяся на вопросах иммиграции в Великобританию, страны ЕС и Карибского региона. Отношение британцев к иммиграции смягчилось. URL: https://www.astons. com/ru/news/otnoshenie-britantsev-k-immigratsii-smyagchilos/ (дата обращения: 8.06.2020). 
“Исследование также показало противоречивость в оценках: $49 \%$ людей согласились с тем, что иммиграция обогатила британскую культуру, а 61\% полагают, что мигранты не смогли интегрироваться в Великобритании”. Кроме того, “47-49\% опрошенных считают, что в Великобританию должны приезжать больше людей для того, чтобы работать медсестрами и врачами"10.

Важные отличия в отночении к иммигрантам в России и Заnaдной Eвропе. Следует заметить, что в отличие от случаев словесных оскорблений, почтовых писем с негативным содержанием, граффити расистского содержания в Великобритании ${ }^{11}$, запретов посещения мигрантам бассейна в Германии ${ }^{12}$, поджогов в приюте в Германии осенью 2015 г. ${ }^{13}$ и во Франции осенью 2016 г. $^{14}$, подавляющее большинство респондентов в г. Москве не сталкивались с подобными фактами агрессии: с получением почтовых писем негативного содержания в адрес мигрантов (99,5\%), граффити расистского содержания $(80,5 \%)$ , физического насилия (73\%), запрета посещения объектов инфраструктуры $(91,5 \%)$ и поджогов места жительства (97\%).

Таким образом, выявленные проблемы отношения к трудовым мигрантам в России не носят такой радикальные характер и не переходят в критические формы, как это происходит в ряде стран Западной Европы. В сравнении с уровнем межэтнической напряженности в Западной Европе, следует отметить, что Россия действительна далека от “мигрантофобии”.

10 Там же.

11 По словам представителя антирасистской организации Far Right Watch Джона О’Коннела, активисты зарегистрировали за первые три дня после проведения референдума о Членстве Великобритании из ЕС более 90 случаев расовой дискриминации самой разной формы: от оскорблений до физического насилия. Например, полякам, живущим в Хантингтоне, по почте отправляли ламинированные карточки с надписями “Мы вышли из ЕС! Нет, польским паразитам!” Также, граффити расистского содержания появились на стенах польского культурного центра в Хаммерсмите и т.д.) (См.: Мануков С. В Великобритании резко выросло число проявлений ксенофобии и расовой дискриминации. URL: https:/expert. ru/2016/06/29/posle-brekzita-v-velikobritanii-rezko-vyiroslo-chislo-proyavlenij-ksenofobii-i-rasovoj-diskriminatsii/ (дата обращения: 29.06.2016)).

${ }^{12}$ Шустер К., Ёлкина А. Беженцам вход воспрещен: меры безопасности или дискриминация? URL: https://p.dw.com/p/1Hknj (дата обращения: 28.01.2016).

${ }_{13}$ Волков К. В Германии подожгли приют для беженцев. URL: https:// rg.ru/2015/10/04/pojar-site-anons.html (дата обращения: 04.10.2015).

${ }^{14}$ Европейская правда. Международная безопасность и евроинтеграция. URL: https://www.eurointegration.com.ua/rus/news/2016/12/16/7059005/ (дата обращения: 16.12.2016). 
8. Отметьте, пожалуйста, сталкивались ли вы или нет за последние 2-3 года со случаями негативного отношения к мигрантам в следующих формах?

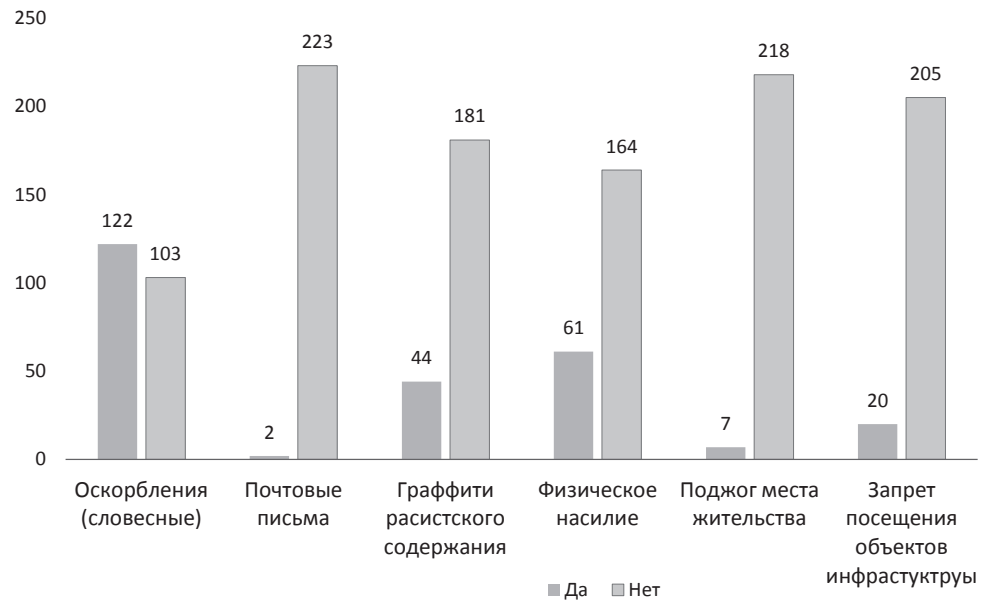

Рис. 8

На вопрос случаются или не случаются конфликты с мигрантами в Москве больше половины респондентов - 52,4\% ответили, что “да, иногда”, а 40,9\% считают, что конфликты “случаются часто”. “Практически нет” считают 6,7\%. в Москве?

9. Как Вы считаете: случаются или не случаются конфликты с мигрантами

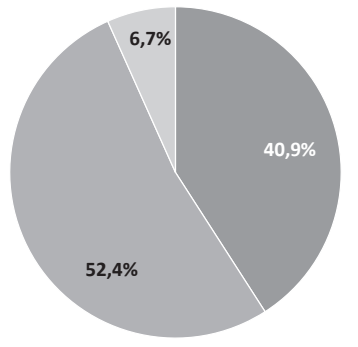

Да, случаются часто

- Да, иногда

Практически нет

Рис. 9

Судя по полученным данным нашего опроса, такое мнение скорее сформировано под воздействием СМИ, чем в результате собственного опыта. 
10. Скажите, пожалуйста, являлись ли вы непосредственным участником конфликта(ов) с мигрантами в следующих сферах жизнедеятельности?

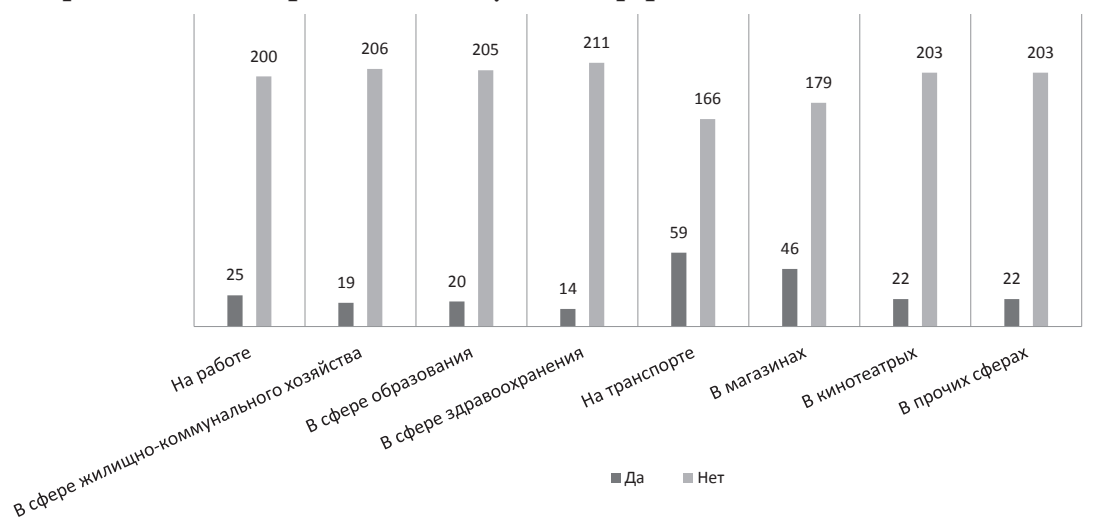

Рис. 10

Абсолютно большинство опрошенных - 89\% (или 200 респондентов из 225 опрошенных) не были непосредственными участниками конфликтов с мигрантами на работе. Также, абсолютное большинство респондентов не вступали в конфликты с мигрантами в сфере жилищно-коммунального хозяйства (ЖКХ) - 91,7\%, в сфере образования - 91,5, в сфере здравоохранения - 94, в кинотеатрах и прочих сферах - 90,5\%. 26\% (59 человек) были непосредственными участниками конфликтов с мигрантами в на транспорте, а 46 человек $(20,3 \%)$ в магазинах.

Причины этносоциальных конфликтов. На открытый вопрос о том по какой причине возник(-ли) конфликт(-ы) с мигрантами, если он(-и) был(-и) были получены самые разнообразные ответы. 57 человек $(25,5 \%)$ отметили по каким причинам у них возникали конфликты, которые можно классифицировать и выделить такие причины: 1) хамство и оскорбления со стороны мигрантов - 11,9\%, 2) различия в культуре и непонимание русского языка - 5,5, 3) невыполнение должностных обязательств со стороны мигрантов - $1,5,4$ ) отсутствие должного уровня квалификации - $1,8,5)$ физическое насилие, драка, причинение ущерба здоровью - 1, 6) дискриминация по национальному признаку $-1,7)$ несоблюдение правил дорожного движения $-0,5,8)$ религиозная одежда $-0,5,9)$ кража и воровство - $1,5,10)$ домогательства со стороны мигрантов - 1, 11) распитие мигрантами спиртных напитков - 0,5\%.

Оставшаяся часть респондентов: 143 человека (63,6\%) отметили, что конфликтов у них с мигрантами не было, а 25 человек $(10,9 \%)$ отказались отвечать на данный вопрос. 
Способы разрешения конфликтов. Отмечая способы разрешения возникших конфликтов самым высоким показателем является 9,3\% респондентов, которые “делали предупреждения” в адрес мигрантов. 64\% отметили, что конфликтов не было.

11. Если Да, то укажите, каким способом Вы пытались разрешить конфликт?

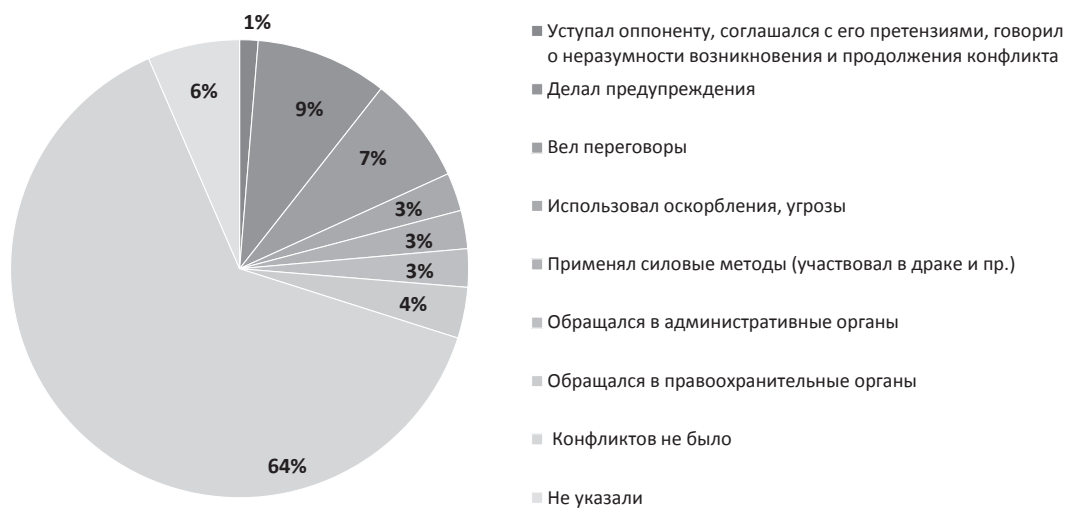

Рис. 11

12. Если Да, то как часто Вам приходилось быть непосредственным участником конфликта(ов) с мигрантами?

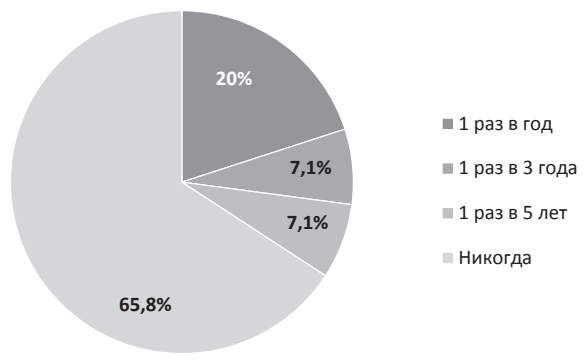

Рис. 12

Одним из важнейших результатов проведенного исследования является следующее. 65,8\% опрошенных никогда не были непосредственными участниками конфликтов с мигрантами. Тем не менее, как было отмечено ранее $40 \%$ опрошенных считают, что иммигранты несут больше проблем, чем блага, 57,3\% считают, что отношение к мигрантам в Москве скорее негативное, чем положительное, а 46,2\% считают, что их число нужно сократить. Это говорит о наличии в 
российском обществе различных этнических стереотипов, а также свидетельствует о том, что представители местного населения Москвы выражают свое мнение не всегда на основании личного опыта, прямого личного контакта с иммигрантами, а на основании общественных суждений, которые зачастую, также, могут быть навязаны средствами массовой информации и пр.

Все это говорит о том, что в стране необходимо проводить самые различные мероприятия по укреплению межнационального согласия, совершенствовать и развивать мероприятия, проводимые на государственном уровне в соответствии со Стратегией государственной национальной политики до 2025 г. Респонденты позитивно относятся к проведению подобного рода мероприятий, о чем свидетельствуют следующие данные.

13. Как Вы считаете: проявляют ли представители различных национальностей в Москве уважительное отношение друг к другу?

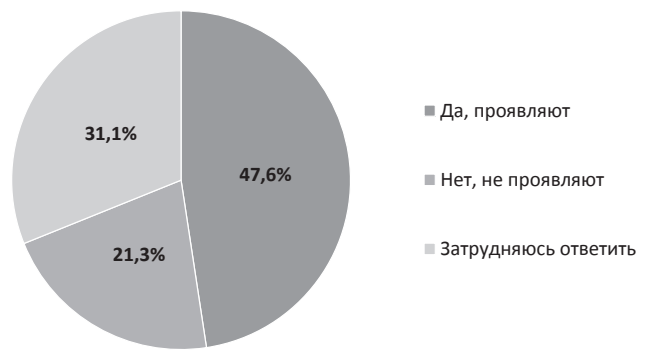

Рис. 13

14. Как Вы относитесь к идее проведения разнообразных мероприятий для представителей различных национальностей с целью знакомства с их культурой, традициями и обычаями?

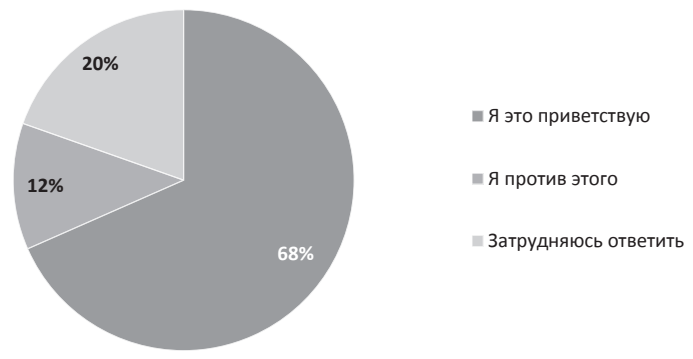

Рис. 14 
Тот факт, что 47,6\%, а это большинство, считают, что представители различных национальностей в Москве проявляют уважительное отношение друг к другу, а 68,4\% приветствуют идею проведения разнообразных мероприятий для представителей различных национальностей с целью знакомства с их культурой, традициями и обычаями, свидетельствует о том, что несмотря на имеющиеся проблемы, этно-социальные конфликты, недопонимания и прочее, в российском обществе наблюдается высокий уровень межэтнической толерантности.

15. Как Вы думаете: что в наибольшей степени разделяет людей разных национальностей? (выберите не более 3-х вариантов ответа?

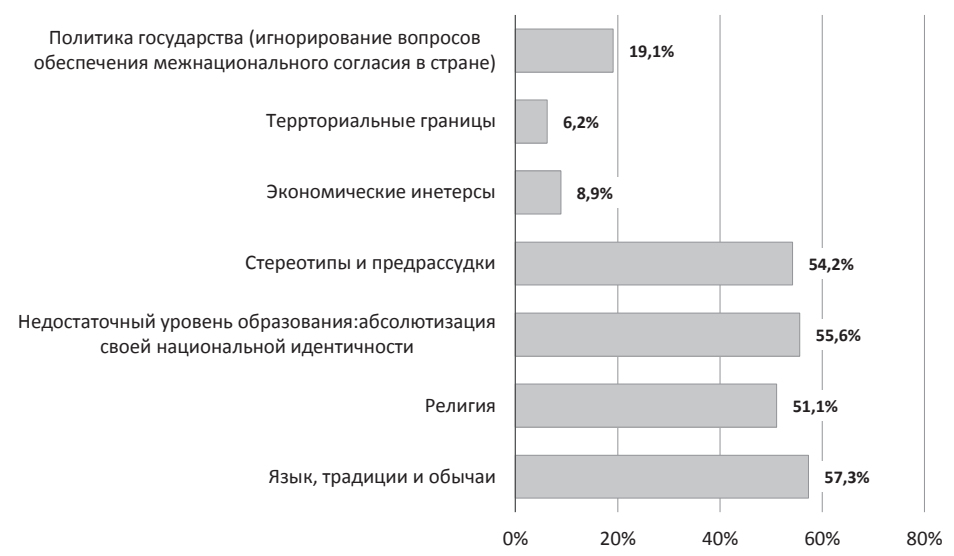

Рис. 15

Что, по мнению опроченных, разделяет людей разных национальностей? 57,6\% считают, что именно язык, традиции и обычаи в наибольшей степени разделяют людей различных национальностей. $55,6 \%$ считают, что людей различных национальностей разделяет недостаточный уровень образования, ведущий к абсолютизации своей национальной идентичности, 54,2\% отметили, что это стереотипы и предрассудки. Подобные результаты свидетельствуют о том, что респонденты осознают, что несмотря на отличия в культуре, языке, обычаях, традициях и других особенностях абсолютизация своей национальной идентичности и желание ставить себя выше других, исходя из своей этнической принадлежности, является отражением недостаточного уровня образования.

Необходимо и впредь поддерживать меры государственной политики, которые способствуют формированию в стране межнациональной гармонии и понимания того, что мы все равны вне зависимости 
от пола, расы, национальности, языка, происхождения, отношения к религии и убеждений, а также, что все возможные случаи дискриминации по национальному и религиозному признаку недопустимы и должны пресекаться.

Таким образом, в ходе проведенного социологического анализа вторичных данных различных исследований в Западной Европе и России, а также анализа данных авторского социологического исследования и последующего их сравнения с результатами опросов в Германии, Франции и Великобритании, можно заключить, что граждане России выражают высокий уровень межэтнической толерантности друг к другу, поскольку, во-первых, осознают необходимость восполнения дефицита рабочих ресурсов в стране за счет трудовых мигрантов из разных стран, а во-вторых, как показало авторское исследование, большая часть опрошенных позитивно относится к тому, что мигранты занимают рабочие места в важных отраслях экономики страны, что свидетельствует о положительной тенденции в российском обществе в отношениях между коренными жителями страны и приезжими мигрантами. Тем не менее, не стоит преуменьшать наличие определенных проблем в межнациональных отношениях, причины которых по результатам опроса, как выяснилось, состоят в том, что иммигранты недостаточно интегрированы в российское общество, зачастую не владеют русским языком на должно уровне и, как следствие, между российскими гражданами и иностранными возникают недопонимания. Кроме того, респонденты отметили, что приезжие ведут себя в ряде случаев “по-хамски, грубо, нагло”, что также говорит о необходимости улучшения социальной адаптации иммигрантов в российское общество и за счет этого минимизировать этносоциальные конфликты на рынке труда и в Росси в целом.

В связи с этим, необходимо рассмотреть существующую государственную политику урегулирования этносоциальных конфликтов на рынке труда в России, о чем более подробно речь пойдет в следующей нашей статье.

Примечание: исследования были бы неполными, если б не были опрошены сами мигранты, занятые на российском рынке труда. В ходе социологического опроса была выявлена удовлетворенность мигрантов состоянием условий труда, заработной платой, отношениями с руководством предприятия, органами государственного управления и с местным населением, удовлетворенность решением вопросов медицинского и социального обеспечения. О результатах мы также расскажем в следующей нашей работе. 


\section{СПИСОК ЛИТЕРАТУРЫ}

Алексашенко С. Как вымирает Россия: выводы из нового демографического прогноза Росстата // Официальный сайт РБК. URL: http://www.rbcdaily.ru/ economy/562949993827108 (дата обращения: 30.01.2015).

Волков К. В Германии подожгли приют для беженцев. URL: https:// rg.ru/2015/10/04/pojar-site-anons.html (дата обращения: 04.10.2015).

Дмитриев А.В. Конфликтология. М., 2002.

Дудуева Ф.А. Научные подходы к исследованию природы и причин этносоциальных конфликтов на рынке труда в России // Социальная политика и социология. 2015. Т. 14. № 4 (111). С. 105-112.

Дудуева Ф.А., Липатова А.Е., Паико А.И. и др. Современные исследования персонала. Проблемы управления персоналом и занятостью в темах диссертационных исследований // Вестник Московского университета. Серия 18. Социология и политология. 2016. № 4.

Европейская правда. Международная безопасность и евроинтеграция. URL: https://www.eurointegration.com.ua/rus/news/2016/12/16/7059005/ (дата обращения: 16.12.2016).

Зайцев А.К. Социальный конфликт. М., 2001. С. 25-32.

Иммиграция в Россию: благо или вред для страны? URL: http://wciom.ru/ index.php?id $=459$ \&uid $=114322$

Кармазин И. Ставрополье превращается в Косово: конфликты русских и мигрантов // Московский комсомолец. 2013. Вып. 26210.

Козер Л. Функции социального конфликта. М., 2000.

Мануков С. В Великобритании резко выросло число проявлений ксенофобии и расовой дискриминации. URL: https:/expert.ru/2016/06/29/posle-brekzitav-velikobritanii-rezko-vyiroslo-chislo-proyavlenij-ksenofobii-i-rasovoj-diskriminatsii/ (дата обращения: 29.06.2016).

Осеев А.А. Социальная напряженность и социальные конфликты в российском обществе: предпосылки, стадии развития и индикаторы // Социальная политика и социология. 2014. № 4 (105). С. 69-83 (ИФ РИНЦ 0,111).

Осеев А.А., Дудуева Ф.А. Особенность этно-социальных конфликтов на российском рынке труда: отношение к иммигрантам в России и Великобритании - сравнительный анализ // Вестник Московского университета. Серия 18. Социология и политология. 2015. № 4.

Осеев А.А., Дудуева Ф.А. Этно-социальные конфликты на рынке труда в России: отношения к иммигрантам в России, Великобритании и Франции // Новое поколение. 2015. № 8. С. 75-77.

Отношение британцев к иммиграции смягчилось. URL: https://www.astons. com/ru/news/otnoshenie-britantsev-k-immigratsii-smyagchilos/ (дата обращения: 08.06.2020).

Отношение европейцев к Исламу и мусульманам: Великобритания, Германия, Франция. URL: http://islam-today.ru/obsestvo/otnoshenie_evropejcev_k_ islamu_i_musulmanam_velikobritaniya_germaniya_franciya/ (дата обращения: 01.02.2013).

Уткин Э.А. Конфликтология. Теория и практика. М., 1998.

Филатов A. Мигранты утопили Германию в криминале. URL: https:/utro. ru/articles/2017/04/28/1325599.shtml (дата обращения: 28.04.2017).

Шустер К., Ёлкина А. Беженцам вход воспрещен: меры безопасности или дискриминация? URL: https://p.dw.com/p/1Hknj (дата обращения: 28.01.2016). 


\section{REFERENCES}

Aleksashenko S. Kak vymiraet Rossiya: vyvody iz novogo demograficheskogo prognoza Rosstata [How Russia is dying out: conclusions from the new demographic forecast of Rosstat] // Oficial'nyj sajt RBK. URL: http://www.rbcdaily.ru/ economy/562949993827108 (data obrashcheniya: 30.01.2015) (in Russian).

Dmitriev A.V. Konfliktologiya [Conflictology]. M., 2002 (in Russian).

Dudueva F.A. Nauchnye podhody k issledovaniyu prirody i prichin etnosocial'nyh konfliktov na rynke truda $v$ Rossii [Scientific approaches to the study of the nature and causes of ethnosocial conflicts in the labor market in Russia] // Social'naya politika i sociologiya. 2015. T. 14. N 4 (111). S. 105-112 (in Russian).

Dudueva F.A., Lipatova A.E., Pashko A.I. i dr. Sovremennye issledovaniya personala. Problemy upravleniya personalom i zanyatost'yu v temah dissertacionnyh issledovanij [Modern research of personnel. Problems of personnel and employment management in topics of dissertation research] // Vestnik Moskovskogo universiteta. Seriya 18. Sociologiya i politologiya. 2016. N 4 (in Russian).

Evropejskaya pravda. Mezhdunarodnaya bezopasnost' i evrointegraciya [European truth. International security and European integration]. URL: https:// www.eurointegration.com.ua/rus/news/2016/12/16/7059005/ (data obrashcheniya: 16.12.2016) (in Russian).

Filatov A. Migranty utopili Germaniyu v kriminale [Migrants drowned Germany in crime]. URL: https://utro.ru/articles/2017/04/28/1325599.shtml (data obrashcheniya: 28.04.2017) (in Russian).

Immigraciya v Rossiyu: blago ili vred dlya strany? [Immigration to Russia: benefit or harm for the country?] URL: http://wciom.ru/index.php?id=459\&uid=114322 (in Russian).

Karmazin I. Stavropole prevrashchaetsya v Kosovo: konflikty russkih i migrantov [Stavropol region turns into Kosovo: conflicts between Russians and migrants] // Moskovskij komsomolec. 2013. Vyp. 26210 (in Russian).

Kozer L. Funkcii social'nogo konflikta [Functions of social conflict]. M., 2000 (in Russian).

Manukov S. V Velikobritanii rezko vyroslo chislo proyavlenij kseno-fobii i rasovoj diskriminacii [The number of manifestations of xenophobia and racial discrimination has sharply increased in Great Britain]. URL: https://expert.ru/2016/06/29/poslebrekzita-v-velikobritanii-rezko-vyiroslo-chislo-proyavlenij-ksenofobii-i-rasovojdiskriminatsii/ (data obrashcheniya: 29.06.2016) (in Russian).

Oseev A.A. Social'naya napryazhennost' i social'nye konflikty v rossij-skom obshchestve: predposylki, stadii razvitiya i indicatory [Social tension and social conflicts in Russian society: prerequisites, stages of development and indicators] // Social'naya politika i sociologiya. 2014. N 4 (105). S. 69-83 (IF RINC 0,111) (in Russian).

Oseev A.A., Dudueva F.A. Osobennost' etno-social'nyh konfliktov na ros-sijskom rynke truda: otnoshenie k immigrantam $\mathrm{v}$ Rossii i Velikobritanii — sravnitel'nyj analiz [The peculiarity of ethno-social conflicts in the Russian labor market: attitudes towards immigrants in Russia and Great Britain - a comparative analysis] // Vestnik Moskovskogo universiteta. Seriya 18. Sociologiya i politologiya. 2015. N 4 (in Russian).

Oseev A.A., Dudueva F.A. Etno-social'nye konflikty na rynke truda v Rossii: otnosheniya k immigrantam v Rossii, Velikobritanii i Francii [Ethno-social conflicts in the labor market in Russia: attitudes towards immigrants in Russia, Great Britain and France] // Novoe pokolenie. 2015. N 8. S. 75-77 (in Russian). 
Oseev A.A., Dudueva F.A., Karacsony P., Vinichenko M.V., Makushkin S.A. The peculiarity of the ethno-social conflicts in the Russian labor market: comparative analysis of Russia, Great Britain and Germany // La peculiaridad de los conflictos etno-sociales en el Mercado laboral en Rusia: un análisis comparativo de Rusia, Gran Bretaña y Alemania. Revista ESPACIOS. 2018. Vol. 39. N 22.

Otnoshenie britancev k immigracii smyagchilos' [British attitudes towards immigration have softened]. URL: https://www.astons.com/ru/news/otnosheniebritantsev-k-immigratsii-smyagchilos/ (data obrashcheniya: 08.06.2020) (in Russian).

Otnoshenie evropejcev k Islamu i musul'manam: Velikobritaniya, Germa-niya, Franciya [The attitude of Europeans towards Islam and Muslims: Great Britain, Germany, France]. URL: http://islam-today.ru/obsestvo/otnoshenie_evropejcev_k_ islamu_i_musulmanam_velikobritaniya_germaniya_franciya/ (data obrashcheniya: 01.02.2013) (in Russian).

Shuster K., Yolkina A. Bezhencam vhod vospreshchen: mery bezopasnosti ili diskriminaciya? [Refugees Not Entry: Security Measures or Discrimination?]. URL: https://p.dw.com/p/1Hknj (data obrashcheniya: 28.01.2016) (in Russian).

Utkin E.A. Konfliktologiya. Teoriya i praktika [Conflictology. Theory and practice]. M., 1998 (in Russian).

Volkov K. V Germanii podozhgli priyut dlya bezhencev [In Germany, a refugee shelter was set on fire]. URL: https://rg.ru/2015/10/04/pojar-site-anons.html (data obrashcheniya: 04.10.2015) (in Russian).

Zajcev A.K. Social'nyj konflikt [Social conflict]. M., 2001. S. 25-32 (in Russian). 